\title{
最近の高分子研究の 動き
}

\section{緒方直哉・田中穂積}

Naoya Ogata - Hozumi Tanaka, 上智大学 理工学部

\section{1. はじめに}

昭和 47 年秋に始まった石油危機は世界経済の大き な変動をもたらしたばかりでなく，高度成長経斉から 安定成長経済へ之政策の大きな転捘をもたらし，人々 の価値判断の規準すら变化を余儀なくした.つをり, 大きいことはよいことであるといら大量消費型の生産 体系から, 付加価值の高い少量生産体系への転換が余 義なくされた。

このよらな社会の動きに対応して当然のことながら 応用工学的色彩が濃い高分子科学の研究の分野におい ても, 破㚾対象や社会のニーズも变化してきている. 今後, 高分子科学がどのような向に動くのかはまだ 漠然としているが，これまでの研究活動をいるいるな 観点からながめて分析してみた.

\section{2. 学会における研究発表の動向}

高分子研究の動向を知るためには，学会に括ける研 究発表の動きをまとめて見ると全体としての方向がよ く理解できる。

\section{2-1. 学会発表}

日本化学会の春季年会 おるび高分子学会年次大会 (5月）に沶いて機関別に発表した研究報告の数を数 年ごとに調べてみた，日本化学会の春季年会での研究 発表注化学の基礎分野から応用分野, また物理化学か ら有機化学のすべての分野にわたっている.この中で 高分子化学に関する研究発表では, 約 7 割は高分子合 成に関す当研究で,物性についての研究発表は少ない.

一方, 高分子学会年次大会での研究発表は高分子科 学阔する分野に限られて特り, 合成, 物性, 応用な ぞのすべての領域にわたっているので, 高分子科学の 動向を知る上では最も適している.

緒方直践 . 上智大学理工学部化学科 (102 東京都千代田区 紀尾井町 7) 教授. 理博 (左)

昭和 29 年東京大学理学部化学科卒. 東レ(株)での研究を経 $\tau ; 41$ 年より現職. 専門は高分子合成. 現在の研究は重縮合 反応，生体関連高分子の合成，機能性高分子材料の合成. く趣味〉スキー, 登山, 酒

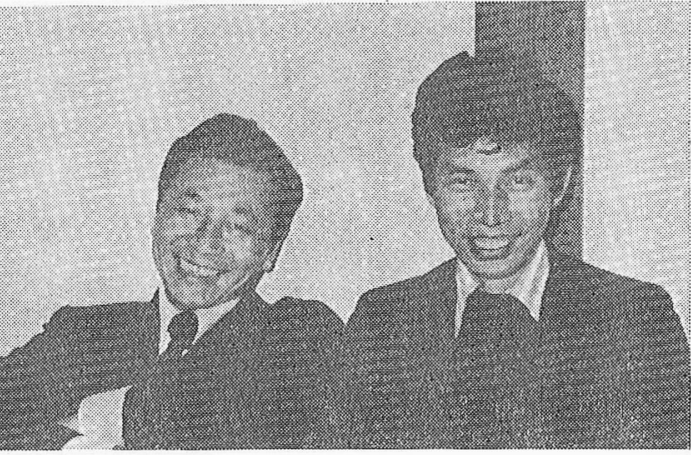

化学全体の動きの中で高分子化学がどのように㡖い ているか比較する意味もあるので、まず日本化学会の 春季年会ならびに高分子学会年次大会について調べ た. 膨大な数にのぼる研究発表の内容について分類す ることは非常に困難であるので, 研究活動のポテンシ ヤルの一つの指針として研究機関別の発表数について まとめてみた。

その結果は第 $1 ， 2$ 表に示した．研究発表数は年次 によってかなり変動しているが, 研究機関ごとの比率 を比較してみると物もしろい，旧帝国大学からの研究 発表は全体の約 35\%を占めて圧倒的に多いが，その 比率自体は年次によってあまり変動していない.

一方, 旧帝国大学以外の国立大学からの研究発表数 は次第に増光て, ほぼ日帝国大学からの研究発表数に 近くなっており, 化学関係の研究が地方国立大学で充 実してきたことを示している.

私立大学加らの研究発表数は国立大学の比率の伸び 湮どには大きくない.

一方, 公立大学からの研究発表数はあまり增減な く，また国立研究機関からの癹表数は減少している。

もっとも減少の傾向が著しいのは, 会社の研究機関 からの発表であり，10年間の間に発表数の比率が春季 年会では $1 / 6$ にも低下した. このことは会社の研究機 関に劣いて, この 10 年間の間に基礎化学についての 研究があまり行なわれなくなったことを物語ってい る.

一方, 高分子学会年次大会に打ける会社関係の研究 発表数は昭和 43 年には $21 \%$ にもの洼, 日本化学 会の場合は昭和 43 年には $12 \%$ であったから, ほぼ 2 倍近い発表であり, 高分子科学の研究が純粋な学閭 分野よりも，応用にかたむいた実学型であることをよ く裏づけている.

\section{田中穂積 同左 ·助手・工博（右）}

昭和 42 年和歌山大学教育学部化学科卒. 44 年上智大大学院修 土課程修了. 同年より現職. 専門は新しい反応を利用した縮 合系ポリマー合成，天然高分子の有効利用，新しい分離膜の 合成，新しい印刷用光橋かけ化合物の合成など. 〈趣味〉水 泳, テニス，美術鑑賞 
全体として日本化学会と高分子 学会年次大会での研究発表を比較 してみると, 大学関係での研究は 盛んに行なわれており, 中でる地 万国立大学の充実が特徴として上 げられるが, 会社関係での研究が この10年間急速に低落している ことは産業界の現実的な動きに対 㐫して, 研究体制が組まれている ためであるが，創造的な技術を生 み出していくためにはもら少し会 社での研究が積極的炕進んでもよ いと思われる. 国立研究機関は大 学と産業界を結ぶ中間的存在とし て意義がめるが, 研究発表数の動 向からみて判断すると, すら少し 研究を促進してもよいのではない だららか。

次に実際に行なわれている研究 内容について分析してみよう．第 3 表惊高分子学会年次大会に和け る研究発表の内容を研究項目に従 って分類した結果である。この表 と, 機関別分類表とでは研究発表
第 1 表 日本化学会春季年会における研究発表の機関別分類

\begin{tabular}{|c|c|c|c|c|}
\hline 分 & $\frac{\text { 昭和 } 43 \text { 年 }}{\text { 件数 }(\%)}$ & $\frac{\text { 昭和 } 47 \text { 年 }}{\text { 件数 }(\%)}$ & $\frac{\text { 昭和 } \mathbf{5 0} \text { 年 }}{\text { 件数 }(\%)}$ & $\frac{\text { 昭和 } \mathbf{5 3} \text { 年 }}{\text { 件数 }(\%)}$ \\
\hline 旧帝国大学 & 1., 197( 38$)$ & $806(35)$ & $855(34)$ & $960(36)$ \\
\hline 国立大学 & $650(20)$ & $562(25)$ & $671(27)$ & $859(32)$ \\
\hline 私立大学 & $390(12)$ & $296(13)$ & $344(14)$ & $394(15)$ \\
\hline 公立大学 & $179(6)$ & $132(6)$ & $122(5)$ & $114(4)$ \\
\hline 国立研究機関 & $354(11)$ & $237(10)$ & $236(9)$ & $239(9)$ \\
\hline 会 社 関 係 & $370(12)$ & $202(9)$ & $226(9)$ & $43(2)$ \\
\hline 外国大学 & $12(0.4)$ & $39(1.7)$ & $25(1.0)$ & $37(1.4)$ \\
\hline 高 & $31(1.0)$ & $8(0.4)$ & $12(0.5)$ & $26(1.0)$ \\
\hline 総 & $3,183(100)$ & $2,282(100)$ & $2,491(100)$ & $2,672(100)$ \\
\hline
\end{tabular}

\section{第 2 表 高分子学会年次大会における研究発表の譏関別分類}

\begin{tabular}{|c|c|c|c|c|}
\hline 分 & $\frac{\text { 昭和 } 43 \text { 年 }}{\text { 件数 }(\%)}$ & $\frac{\text { 昭和 } 47 \text { 年 }}{\text { 件数 }(\%)}$ & $\frac{\text { 昭和 } \mathbf{5 0} \text { 年 }}{\text { 件数 }(\%)}$ & $\frac{\text { 昭和 } \mathbf{5 3} \text { 年 }}{\text { 件数 }(\%)}$ \\
\hline 旧帝国大学 & $212(36)$ & $209(33)$ & $195(32)$ & $245(32)$ \\
\hline 国 立大学 & $112(19)$ & $152(24)$ & $198(33)$ & $226(30)$ \\
\hline 私立大学 & $60(10)$ & $82(13)$ & $74(12)$ & $96(13)$ \\
\hline 公立大学 & $23(4)$ & $18(3)$ & $19(3)$ & $30(4)$ \\
\hline 国立研究機関 & $57(10)$ & $72(11)$ & $60(10)$ & $59(8)$ \\
\hline 会 社 関 係 & $124(21)$ & $92(14)$ & $58(10)$ & $73(9)$ \\
\hline 外国大学 & $3(0.5)$ & $3(0.5)$ & $3(0.5)$ & $21(3)$ \\
\hline 専 & $1(0.2)$ & $7(1.1)$ & $2(0.3)$ & $11(1.5)$ \\
\hline 計 & $592(100)$ & $635(100)$ & $609(100)$ & $761(100)$ \\
\hline
\end{tabular}

第 3 表 高分子学会年次大会研究発表の分類

\begin{tabular}{|c|c|c|c|c|c|c|c|c|c|c|c|c|c|c|c|c|c|c|c|c|c|c|}
\hline 分類 ${ }^{\text {昭和 }}$ & 30 & 31 & 32 & 33 & 34 & 35 & 36 & 39 & 41 & 42 & 43 & 44 & 45 & 46 & 47 & 48 & 49 & 50 & 51 & 52 & 53 & 54 \\
\hline \multicolumn{23}{|l|}{ 合成反応 } \\
\hline ラジカル重合 & 合 6 & 7 & 9 & 7 & 11 & 20 & 15 & 30 & 48 & 72 & 63 & 65 & 59 & 51 & 43 & 58 & 43 & 60 & 57 & 57 & 50 & 56 \\
\hline 電荷移動重合 & 合 - & - & - & - & - & - & - & - & 21 & 12 . & 13 & 13 & 12 & 4 & 5 & 0 & - & - & - & - & - & - \\
\hline カチオン重合 & 合 0 & 2 & 2 & 4 & 2 & 5 & 7 & 9 & 12 & 22 & 18 & 15 & 14 & 13 & 6 & 12 & 12 & 10 & 11) & \multirow{2}{*}{31} & 10 & 4 \\
\hline $\boldsymbol{ア} ン$ オン重合 & 合 0 & 1 & 0 & 0 & 2 & 4 & 7 & 11 & 11 & 26 & 40 & 27 & 20 & 26 & 16 & 15 & 24 & 9 & $13\}$ & & 10 & 13 \\
\hline 配 位 重 合 & 合 0 & 0 & 2 & 13 & 9 & 10 & 15 & 14 & 21 & 24 & 8 & 10 & 13 & 16 & 8 & 7 & 8 & 4 & 4 & - & 8 & 9 \\
\hline 重 縮 & 合 6 & 2 & 3 & 2 & 5 & 10 & 2 & 24 & 20 & 24 & 30 & 33 & 19 & 21 & 27 & 28 & $21)$ & \multirow{2}{*}{25} & 17 & 29 & 25 & 22 \\
\hline 付 & 2 & 1 & 2 & 0 & 0 & 0 & 2 & 7 & 0 & 0 & 0 & 18 & 3 & 0 & 12 & - & $4\}$ & & 5 & 8 & 4 & 6 \\
\hline 開 環 重 合 & 合 1 . & 0 & 4 & 4 & 2 & 3 & 0 & 19 & 23 & 28 & 18 & 3 & 15 & 28 & 13 & 21 & 16 & 21 & 20 & 30 & 21 & 26 \\
\hline 放射線·光重 & 合 0 & 2 & 4 & 14 & 38 & 35 & 63 & 37 & 29 & 24 & 11 & 13 & 22 & 33 & 9 & 35 & 27 & 31. & 23 & 21 & 22 & 17 \\
\hline 高分子反応 & 心 0 & 3 & 4 & 6 & 10 & 4 & 14 & 8 & 18 & 17 & 26 & 25 & 9 & 55 & 28 & 54 & 30 & 42 & 33 & 59 & 40 & 42 \\
\hline 分解·劣 化 & 化 3 & 3 & 4 & 1 & 2 & 3 & 1 & 0 & 3 & 9 & 14 & 18 & 16 & 14 & 20 & 23 & 22 & 19 & 26 & 24 & 15 & 11 \\
\hline 高分子触媒 & 某 - & - & - & - & - & - & - & - & - & - & - & - & - & 11 & 16 & 9 & 24 & 35 & 25 & 33 & - & - \\
\hline 生体高分子 & 子 - & - & - & - & - & - & - & - & - & - & - & - & - & - & - & - & - & - & 44 & 55 & 61 & 63 \\
\hline 機能性高分子 & 子 - & - & - & - & - & - & - & - & - & - & - & - & - & - & - & - & - & - & - & - & 106 & 97 \\
\hline \\
\hline 固体物性 & 17. & 17 & 17 & 46 & 16 & 38 & 30 & 13 & 74 & 75 & 85 & 75 & 74 & 9 & 100. & 113 & 83 & 105 & 87 & 127 & 86 & 84 \\
\hline 固体構造 & & & & & 18 & 20 & 26 & 69 & 46 & 38 & 47 & 26 & 30 & 49 & 57 & 53 & 43 & 34 & 42 & 28 & 53 & 41 \\
\hline 溶液物性 & 15 & 16 & 33 & 23 & 40 & 40 & 35 & 87 & 45 & 62 & 67 & 20 & 96 & 91 & 117 & 79 & 42 & 49 & 50 & 60 & 61 & 53 \\
\hline 成形加工 & 7 & 0 & 12 & 5 & 15 & 15 & 8 & 26 & 28 & 15 & 15 & 22 & 18 & 21 & 22 & 38 & 14 & 14 & 20 & 18 & 42 & 31 \\
\hline \multicolumn{23}{|l|}{ まとめ } \\
\hline 合成関係 & 18 & 21 & 34 & 51 & 81. & 94 & 126 & 159 & 185 & 246 & 249 & 239 & 203 & 281 & 210 & 266 & 236 & 256 & 278 & 347 & 372 & 366 \\
\hline 物珄関係 & 39 & 33 & 62 & 74 & 89 & 113 & 99 & 195 & 193 & 190 & 214 & 143 & 218 & 251 & 296 & 283 & 182 & 202 & 199 & 233 & 242 & 209 \\
\hline 計 & 57 & 54 & 96 & 125 & 170 & 207 & 225 & 354 & 378 & 382 & 463 & 382 & 421 & 532 & 506 & 549 & 418 & 458 & 477 & 580 & 614 & 575 \\
\hline
\end{tabular}


の総数が一致していないがこれは機関別分類では一 つの研究発表であっても共同研究として二つ以上の研 究機関が関与している場合があるからである。

研究内容別分類表の結果をながめてみると, 時代と ともに研究対象の興味がぞのように動いていったかが よく現われている。

例えば，合成部門ではラジカル重合，イオン重合， 重縮合など重合反応の基礎的な分野での研究は毎年着 夷に行なわれて和り，研究発表数も增学ていってい る.ところが，配位重合，つまりチーグラ一触某によ る重合反応についての研究は昭和 42 年をピークにし ている。また放射線, 光重合の分野では昭和 36 年に ピークがあり，いったん減少して昭和 45 年から再び 增加している。これは，昭和 36 年のピークは放射線 重合反応火関方名研究に依存するものであり，いった ん研究活動が低下して今度は光重合反応についての研 栄が盛んになってきたためである。

一方, 合成反応の分野では高分子反応, 生体高分子 反応についての研究が著しく盛んになっている，この 分野以機能性高分子の合成につながる分野であり，実 際，第 3 表中に示されている通り，昭和 53 年からは 譏能性高分子の研究項目が高分子学会年次大会の中に 取り上げられて出現している。

いったい，いつ頃から機能性高分子についての研究 が盛んになったのかを，はっきり示すのは困難である が，高分子触媒の研究項目が年次大会に登場した昭和 46 年と見ることができる。この年は翌昭和 47 年秋の 石油危機を契機とする世界的な経济变動の盰期がやが て訪れようとしていた年である。

高分子化学の中に一つの転換をるたらした機能性高 分子が, 世界的経済の転換期や，人間の価值観の変動 の時期とほぼ対応して登場したのは必ずしも偶然とは 言兄ないだらう、特に高分子科学のように実学型の研 究分野では社会の動きに敏感に対応しているのは当然 ともい学る. 高分子学会年次大会での研究項目の分類 はある意味で極めてオーソドックスであり，時代とと あに変化する研究対象やニーズを必ずしも的確には区 映していない，一つの分析の仕方は高分子討諭会の特 定テーマを見ることである. 昭和 47 年から高分子討 論会では従来の研究項目に加兄て, 特定テーマ制度を 設けた、つまりある特定テーマを設定し，この分野に 関連する研究を集めて発表させて, 討論を深めよらと するものである. 当初, 特定テーマの設定に関しては 一種の研究統制であるとして反対の考方方るあった が, 学術的研究が増えてくるにつれて旧来の分類には 入らなくなってきたために，今日至る亦で毎年継続 さ礼ている.
第 4 表 高分子討論会特定テーマ

\begin{tabular}{|c|c|c|}
\hline $\begin{array}{l}\text { 昭和 } \\
\text { 年次 }\end{array}$ & 特定テーマ & $\begin{array}{l}\text { 発表 } \\
\text { 件数 }\end{array}$ \\
\hline \multirow{3}{*}{47} & 機能胜高分子 & 13 \\
\hline & 分子設計 & 9 \\
\hline & 高分子膜 & 5 \\
\hline \multirow{7}{*}{48} & 高分子の生長末端 & 16 \\
\hline & 反応に祘ける高分子効果 & 9 \\
\hline & ラジカル重合に拈ける溶媒効果 & 9 \\
\hline & 高分子金属錯体の触媒作用 & 7 \\
\hline & 高分子の崩壊現象 & 9 \\
\hline & 高分子膜 & 4 \\
\hline & 高分子の界面科学 & 10 \\
\hline
\end{tabular}

機能性高分子のデザインと合成 10 高分子の触媒作用 11

49 モノマーの構造と重合反応性 10 乳化重合とェマルショョンの物性 8 共重合反応の規制 8

\begin{tabular}{clr}
\hline \multirow{4}{*}{50} & 機能性高分子 & 45 \\
& 光伝導性高分子 & 8 \\
& 耐熱性高分子 & 5 \\
& 界面と高分子 & 15 \\
\hline \multirow{3}{*}{51} & 重合に怙ける選択性と特異性 & 24 \\
& オリコマーの化学 & 9 \\
& エネルギー変換 & 11 \\
& 高分子の分離機能 & 14 \\
& 高分子系の界面 & 8 \\
\hline
\end{tabular}

重合飞和计る選択性と特異性 24 オリゴマーの特性 6 エネルギー変換 9

52 高分子効果 20

高分子の分離機能 12

高分子と材料科学到 13

生体膜の構造と機能 6

高分子と生体との相互作用年 6

不斉重合に打ける活性種と巽択性 8

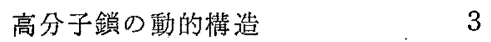

画像形成材料 6

高分子系相互作用特異性之機能 11

固相特よび融液系に打故る反応 5

53 高分子触煤のミク口環境

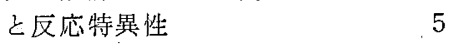

高分子材料の生体適合性 10

合成ポリペプチドの機能 と側鎖の構造 8

選択分離膜 13

異種ポリマー間の相溶性列的

重合に拈ける立体化学 19

高分子の相互作用と機能 $\quad 30$

高分子の光化学 17

54 生体高分子工学 12

高分子獏 14

高分子多相系公 7

高分子液晶 11

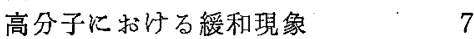


第 4 表は高分子討論会の特定テ 一マと発表件数が示してある. 昭 和 47 年以はまず機能性高分子が 登場している. 分子設計, 高分子 膜も离る意味では機能性高分子で あり, 関心の高まりは, 高分子学 会年次大会の分析とほぼ一致して いる. 高分子討論会の特定テーマ は毎年变わって扣り，また発表件 数も变化しているが, 一貫して続 いているニーズとしては機能性高 分子と, 重合反応注拈活る反応制 御，つ娄り自由に好きな形の高分 子を作ららといら研究の二つがあ る.

機能性高分子の一分野として生 体関連高分子が尔るが，だいたい 昭和 50 年頃から関心が急速に高 まったといえる。

高分子材料が金属や木材にかわ る構造材料として世の中に登場し て, 確固とした地位を築いた昭和 40 年当初の頃から, 次の 新しい 方向に向かっての模索が始まった の昭昭和 42 年 43 年頃と思われ るが, 昭和 47 年の石油危機を契 機として，高分子が単なる構造材 料から機能材料へと転換していく 様子が, 学会の研究発表を見ても よく理解することができる。

\section{2-2. 研究論文}

学会に䑙汀口頭発表は研究活 動の重要なバロメータであるが, 口頭による発表はプログラムと要 旨以外には記録に残らないため に，ただ発表したといら実績が残るだけであるが，研 究論文は学会発表に比べてはるか性容も充実してい るし, 著者の責任も要求される.

研究論文の内容を検討してみるのも，研究動向を知 る上で大変参考湾なる、まず化学全体の傾向を見る意 味で, 日本化学会の諭文誌である Bulletin of Chemical Society of Japan および日本化学会誌につい て調べた. 日本化学会誌は工業化学雑誌と日本化学雑 誌を合併したので, 昭和 47 年をでは工業化学雑誌に ついて調べた.

第 5 表は, Bulletin，第 6 表は日化誌の論文の機関 別分類をまとめたものである。 まず Bulletin につい
第 5 表 Bull. Chem. Soc. Japan の論文の機関別分類

\begin{tabular}{|c|c|c|c|c|}
\hline 昭和年次 & 43 & 47 & $\mathbf{5 0}$ & 53 \\
\hline 分類 & 件数 $(\%)$ & 件数 (\%) & 件数 $(\%)$ & 件数 $(\%)$ \\
\hline 旧帝国大学 & $356(46)$ & $420(42)$ & $414(41)$ & $352(37)$ \\
\hline 国立大学 & $175(23)$ & $255(26)$ & $286(28)$ & $262(28)$ \\
\hline 私立大学 & $51(7)$ & $87(9)$ & $106(11)$ & $109(11)$ \\
\hline 公立大学 & $51(7)$ & $54(5)$ & $56(6)$ & $54(6)$ \\
\hline 国立䂤究機関 & $47(6)$ & $64(6)$ & $62(6)$ & $76(8)$ \\
\hline 会 社 関 係 & $68(9)$ & $70(7)$ & $48(5)$ & $43(5)$ \\
\hline 外国大学 & $28(4)$ & 49( & $37(4)$ & $51(5)$ \\
\hline 専 & $0(0)$ & $0(0)$ & $0(0)$ & $5(0.5)$ \\
\hline 計 & $776(100)$ & $999(100)$ & $1,009(100)$ & $952(100)$ \\
\hline
\end{tabular}

第 6 表 日本化学会誌の論文の機関別分類

\begin{tabular}{|c|c|c|c|c|}
\hline 昭和年次 & 43 & 47 & 50 & 53 \\
\hline 分類 & 件数 $(\%)$ & 件数 $(\%)$ & 件数 $(\%)$ & 件数 $(\%)$ \\
\hline 旧帝国大学 & $179(27)$ & $127(20)$ & $100(19)$ & $67(16)$ \\
\hline 国立大学 & $129(20)$ & $197(31)$ & $150(28)$ & $129(32)$ \\
\hline 私立大学 & $67(10)$ & $83(13)$ & $86(16)$ & $100(25)$ \\
\hline 公立大学 & $30(5)$ & $34(5)$ & $30(6)$ & $9(2)$ \\
\hline 国立研究機関 & $63(10)$ & $82(13)$ & $77(15)$ & $50(12)$ \\
\hline 会 社 関 係 & $177(27)$ & $113(18)$ & $65(12)$ & $49(12)$ \\
\hline 外国大学 & $1(0.2)$ & $1(0.2)$ & $1(0.2)$ & $0(0)$ \\
\hline 専 & $8(1)$ & $9(1)$ & $15(3)$ & $5(1)$ \\
\hline 計 & $659(100)$ & $643(1.00)$ & $527(100)$ & $408(100)$ \\
\hline
\end{tabular}

第 7 表 高分子論文集の論文の機関別分類

\begin{tabular}{|c|c|c|c|c|}
\hline 昭和年次 & 43 & 47 & 50 & 53 \\
\hline 分類 & 件数 $(\%)$ & 件数 $(\%)$ & 件数 $(\%)$ & 件数 $(\%)$ \\
\hline 旧帝国大学 & $26(23)$ & $45(19)$ & $10(7)$ & $9(6)$ \\
\hline 国立大学 & $24(21)$ & $50(21)$ & $30(22)$ & $46(31)$ \\
\hline 私 立 大 学 & $17(15)$ & $31(13)$ & $23(17)$ & $29(20)$ \\
\hline 公立大学 & $6(5)$ & $5(2)$ & 3( & $4(3)$ \\
\hline 国立研究機関 & $10(9)$ & $15(6)$ & $21(15)$ & $9(6)$ \\
\hline 会 社 関 係 & $32(28)$ & $94(39)$ & $48(35)$ & $50(34)$ \\
\hline 外国大学 & $0(0)$ & $0(0)$ & 0( & $0(0)$ \\
\hline 高 & $0(0)$ & $1(0.4)$ & $3(2)$ & $1(0.7)$ \\
\hline 総 & $115(1.00)$ & $241(100)$ & $138(100)$ & $148(100)$ \\
\hline
\end{tabular}

て見ると昭和 43 年には旧帝国大学からの発表が $46 \%$ で約半分を占めていたが, 昭和 53 年には $37 \%$ に娍 少した. 一方, 他の国立大学からの発表は增加してお。 り，口頭発表の場合之同様に地方の国立大学での研究 が充実してきていることをよく裏づけている，私立大 学からの論文発表はこの間に $7 \%$ から $11 \%$ と増克, 私立大学の研究の質の向上がこれかららかがえる。

さて, 日本化学会誌の傾向を見てみよう. 第6表に 見られるように，旧帝国大学からの論文発表件数は Bulletin に比べるとはるが低いが，これは当時の 工業化学雑誌の時の分類であるため, 応用化学の色彩 が強い論文が主体であるからである、特に会社関係の 
第 8 表 Polymer Journal の論文の機関別分類

\begin{tabular}{|c|c|c|c|c|}
\hline 昭和年次 & 45 & 47 & 50 & 53 \\
\hline 分類 & 件数 $(\%)$ & 件数 （\%) & 件数 $(\%)$ & 件数 $\quad(\%)$ \\
\hline 旧帝国大学 & $67(56)$ & $55(44)$ & $38(35)$ & $35(32)$ \\
\hline 国立大学 & $8(7)$ & $18(14)$ & $22(20)$ & $18(17)$ \\
\hline 私 立 大学 & $1(1)$ & $7(6)$ & $8(6)$ & $11(10)$ \\
\hline 公 立 大学 & $0(0)$ & $3(2)$ & $1(1)$ & $1(1)$ \\
\hline 国立研究機関 & $8(7)$ & $7(6)$ & $5(5)$ & $3(3)$ \\
\hline 会 社 関 係 & $28(24)$ & $21(21)$ & $11(10)$ & $13(12)$ \\
\hline 外国大学 & $7(6)$ & $9(7)$ & $24(22)$ & $26(19)$ \\
\hline 専 & $0(0)$ & $0(0)$ & $0(0)$ & $1(1)$ \\
\hline 計 & $119(100)$ & $125(100)$ & $109(100)$ & $108(100)$ \\
\hline
\end{tabular}

第 9 表 J. Polymer Sci. の論文の機関別分類

\begin{tabular}{|c|c|c|c|c|}
\hline 昭和年次 & 43 & 47 & 50 & 53 \\
\hline 分類 & 件数 $(\%)$ & 件数 $(\%)$ & 件数 $(\%)$ & 件数 (\%) \\
\hline 旧帝国大学 & $100(15)$ & $56(8)$ & $60(9)$ & $49(8)$ \\
\hline 国立大学 & $11(2)$ & $22(3)$ & $29(5)$ & $38(6)$ \\
\hline 私立大学 & $6(1)$ & $10(1)$ & $18(3)$ & $16(2)$ \\
\hline 公立大学 & $13(2)$ & $11(2)$ & $14(2)$ & $8(1)$ \\
\hline 国立研究機関 & $30(4)$ & $46(7)$ & $25(4)$ & $26(4)$ \\
\hline 会 社 関 係 & $31(5)$ & $26(4)$ & $16(3)$ & 9( \\
\hline 外国大学 & $479(71)$ & $504(75)$ & $475(74)$ & $495(77)$ \\
\hline 高 & $1(0.1)$ & $1(0.1)$ & $1(0.1)$ & $1(0.1)$ \\
\hline 総 & $671(100)$ & $676(100)$ & $638(100)$ & $642(100)$ \\
\hline
\end{tabular}

第 10 表 高分子論文集の論文の分類

\begin{tabular}{|c|c|c|c|c|c|}
\hline & 分類 昭和年次 & 43 & 48 & 50 & 51 \\
\hline & ラジカル重合 & 16 & 21 & 16 & 20 \\
\hline & 電荷移動重合 & 0 & 0 & 0 & 0 \\
\hline & カチオン重合 & 3 & 3 & 1 & 0 \\
\hline \multirow[t]{2}{*}{ 合 } & アニオン重合 & 6 & 4 & 0 & 1 \\
\hline & 配位重合 & 4 & 1 & 1 & 0 \\
\hline \multirow[t]{2}{*}{ 成 } & 重縮合 & 5 & 17 & 9 & 11 \\
\hline & 重付加 & 1 & 2 & 2 & 0 \\
\hline \multirow[t]{2}{*}{ 反 } & 開環重合 & 2 & 8 & 3 & 3 \\
\hline & 放射線. 光重合 & 7 & 3 & 5 & 4 \\
\hline \multirow[t]{6}{*}{ 姲 } & 高分子反応 & 18 & 17 & 8 & 5 \\
\hline & 分解 · 劣化 & 4 & 12 & 7 & 6 \\
\hline & 高分子触媒 & 0 & 0 & 0 & 0 \\
\hline & 生体高分子 & 0 & 0 & 0 & 0 \\
\hline & 機能性高分子 & 0 & 1 & 1 & 0 \\
\hline & 固体物珄 & 13 & 12 & 15 & 16 \\
\hline \multirow{3}{*}{$\begin{array}{l}\text { :物 } \\
\text { 性 }\end{array}$} & 固体構造 & 8 & 8 & 12 & 13 \\
\hline & 溶液物性 & 21 & 11 & 14 & 8 \\
\hline & 成形加工 & 8 & 21 & 22 & 16 \\
\hline \multirow{3}{*}{$\begin{array}{l}\text { क } \\
\text { ऐ } \\
\text { め }\end{array}$} & 合成関係 & 66 & 89 & 53 & 50 \\
\hline & 物性関係 & 50 & 52 & 63 & 53 \\
\hline & 計 & 116 & 141 & 116 & 103 \\
\hline
\end{tabular}

論文の急落が著しい。雨者の傾向は Bulletin よよく 一致している.
一方，地方国立大学特よび私立 大学からの論文は増加しており, いずれも研究活動が充実している ことを示している.

それでは，高分子科学関係の研 究の実状について高分子論文集を 取り上げて分析してみよう、第 7 表は高分子論文集に揭載された論 文の機関別分類である.もらろん 過去の資料については高分子論文 集の前身である高分子化学につい て調ベたものである.

表から明らかなように，旧帝国 大学からの論文が次第に減少して 招り，この傾向は Bulletin，日 化誌とよく一致している. 一方, 地方国立大学と私立大学からの論 文は増加している. 公立大学和よ び国立研究機関の論文数はいくら か変動はあるものの, あまり変化 が見られない。

また，会社関係からの論文数は 横ばいになっている。このことは 学会に报当研究発表や，日本化 学会の論文で会社関係からのものが急落していること と照らし合わせてみると大变叔もしろい傾向である。 現在の高分子論文集の前身は高分子化学であり，その 名前が示すと物り前身の高分子化学の内容は合成と物 珄が中心であった．実学的色彩の強い高分子科学の研 究では，学術的研究は当然必要ではあるが，同時に工 学的研究も盛九に行なわれており，これらの研究にも 発表の場を与觉てもよいのではないかといら考点から 高分子論文集と名前が改められた．この編集方針の変 化が会社関係からの論文数の維持につながっていると 見ることができる。

高分子学会の英文雑誌である Polymer Journal の 分析結果について述べう．第8表はPolymer Journal の論文の機関別分類の結果をまとめたものであ る. 昭和 45 年には旧帝国大学からの論文は $56 \%$ で 半数以上を占めていたが，次第に告の比率は減少し た. 一方, 地方国立大学と私立大学からの論文比率は 急增している. 公立大学, 国立研究機関加らの諭文比 率はあまり変化がない。

しかし，会社関係からの論文比率は次第に減少し た。このことは日本化学会刊行の雑誌での傾向と一致 するが，高分子論文集での傾向とは異なる. Polymer Journal の論文は学術論文が多いことがこのような現 
第 11 表 高分子論文集の特集テーマ

\begin{tabular}{lrll}
\hline 巻 & 号 & 年 & テ ー マ \\
\hline 34 & 4 & 1977 & 医用高分子-1 \\
34 & 10 & 1977 & 膜 \\
35 & 4 & 1978 & 界面 \\
35 & 10 & 1978 & オリダマー \\
36 & 4 & 1979 & 医用高分子-2 \\
36 & 10 & 1979 & フォトポリーー \\
\hline
\end{tabular}

象をもたらしたと理解できる。一方，外国大学からの

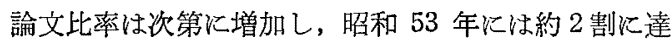
して拈り，国際的性格が增している。

高分子化学の論文雑誌の中で古くから刊行され, 権 威のあるアメリカの Journal of Polymer Science について調ベてみた。

第 9 表は分類した結果をまとめたものである。当然 のことながら，外国大学や外国研究機関からの論文の 比率は高く 71〜77\% を占めている. しかし，アメリ カの雑誌でありながら, 日本からの諭文が 3 割近くを

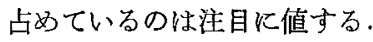

日本からの諭文のうち，地方国立大学叔よび私立大

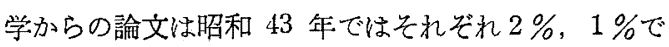
めったものが，昭和 53 年には $6 \% ， 3 \%$ と增加して いる. 公立大学, 国立研究機関からの論文数の变動は ないが，会社関係からの諭文は昭和 43 年の $5 \%$ から， 昭和 53 年には $1 \%$ 落ちこえでいる。こ礼らの傾向 は単純に比較できないが，日本での傾向とよく一致し ている.しかし外国誌については，一誌作定してい るためより誹しい調查により判断する必要がある。

学術雑誌に掲載された論文を機関別に分類してみる と, 高分子論文集に抬りる会社関係の研究論文を除い てはよく一致して招り，地方国立大学拉よび私立大学 は向上しているのに対し, 旧帝国大学亡公立大学, 国 立研究機関および会社関係の研究の停滞をよく示して いる.もちろん, これらの分析は単なる発表数, 諭文 数の単純な比較にすぎず, その内容や質の問題には全 くふれていないし, また対象にした雑誌の数も少ない ので単純な結論は下せないが, 研究活動の全般的な動
向をつかむ資料にはなると思う。

さて, 研究諭文の内容別の分類について高分子論文 集を取り上け゚て分析してみ上う. 第 10 表は高分子論 文集（高分子化学）飞揭載されて論文の内容を, 高分 子学会年次大会における研究項目分類に従ってまとめ. たるのである.この結果を第 2 表の高分子学会年次大 会の研究発表と比較してみると，卧济対応しているこ 之がわかる. 合成関係の論文で压倒的に多いのはラジ カル重合, 重縮合であるが, 機能性高分子の合成につ. ながる高分子反応の研究についての報告も多い，一 方, 成形加工などの工学的分野での研究発表もかなり 多くなされて和り, 前述のような高分子諭文集の編集 方針がよく反映している。

高分子論文集の特集号のテーマについてまとめたの. が第 11 表俰示してある. 高分子討論会での特定テー マと対比してわかると和り，機能性高分子の合成和よ び物性汇関する䂥究がテーマとして取り上げられてい， る.るらろん, これらの研究が全体の流れを支配して いるとはい充ないが，関心が持たれている分野である ことは確かである。

このようにしてみると高分子科学の分野では基礎研 究は依然として行なわれているすのの, 全体として特: 異な機能や性質を有する高分子についての関心が最近 は非常に高いことがわかる。

\section{ま.とめ}

高分子科学の分野での研究動向をさぐるために，学: 会に括斿る口頭発表就よび論文について内容別, 機関、 別, 年次別淿いるいるな角度から眺めてみた. 研究機 関についてみると，旧帝国大学での集中研究から，分 散的研究に移行している過程が明らがされた，同様: のことが研究内容についてもい光，多彩な性能を持っ た高分子をどのようにして生み出すが今後の方向が あると思う。

亲た今回の分析は，日本を中心としたが，外国雑誌。 への諭文投稿は年々増加して特り，高分子科学の研究 動向をより詳しく検討するには，外国雑誌の調查を行 なら必要があると考兄られる。 